Dep. of Bacteriology,

Animal Health Research Institute,

Mansoura Laboratory.

\title{
SOME BACTERIOLOGICAL STUDIES ON RESPIRATORY AFFECTIONS IN CALVES AMONG BUFFALO FARM IN DAKAHLIA GOVERNORATE
}

(With 5 Tables)

By

M.M. ABD EL-LATIF

(Received at 15/3/2011)

بعض الاراسات البكتيريولوجية على الإصابات التنفية في في عجول

محمود محمد محمود عبل اللطبف

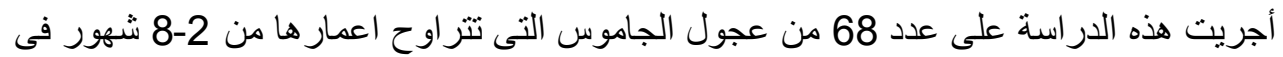

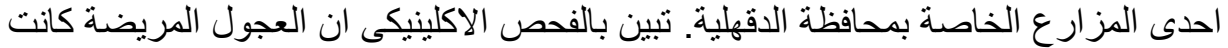

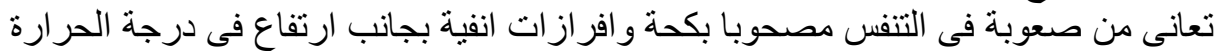

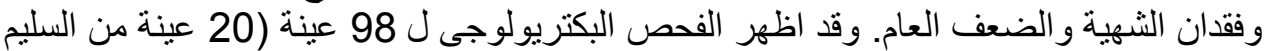

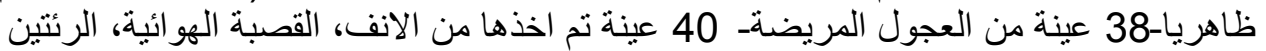

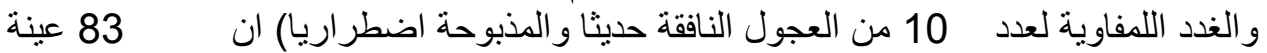

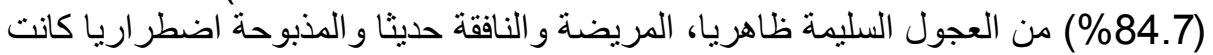

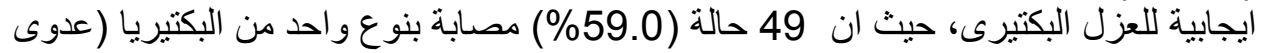

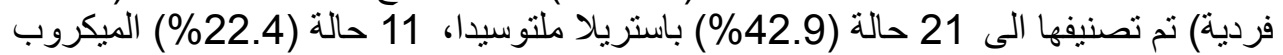

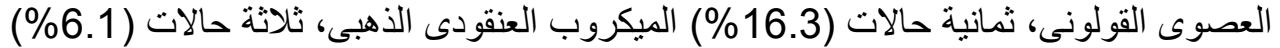

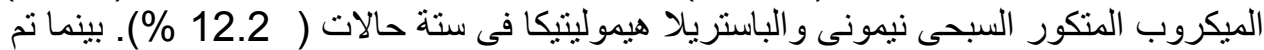

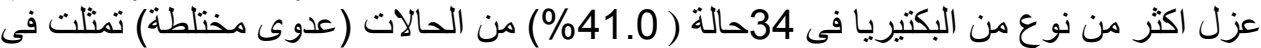

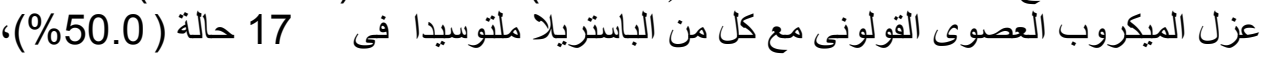

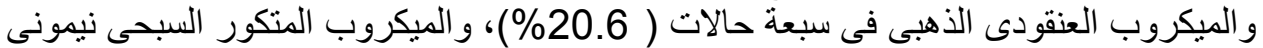

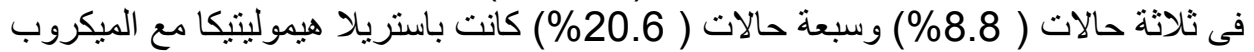

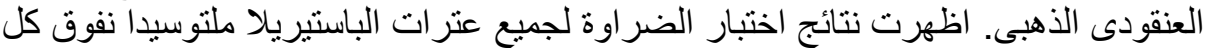
الفئران المحقونة خلال البكتيرية شديدة الحساسية لكل من الانروفلوكساسين، و الفلوروفينكول. 


\section{SUMMARY}

This study was carried out on 68 buffalo-calves aged from 2-8 month from a private farm in Dakahlia Governorate .Diseased calves were suffering from severe dyspnoea, cough, nasal discharge, pyrexia and abnormal lung sounds. Bacteriological examination of 98 samples (20 clinically healthy, 38 clinically diseased and 40 samples from each the nose, trachea, lung and lymph nodes of 10 freshly dead and emergency slaughtered calves) revealed that $83(84.7 \%)$ samples from clinically healthy calves, diseased and freshly dead and emergency slaughtered calves were positive for bacterial infection where $49(59.0 \%)$ were as a single infection identified as Pasteurella multocida21(42.9\%), E.coli 11(22.4\%), Staph. aureus $8(16.3 \%)$, Streptococcus pneumoniae 3(6.1\%) and P.haemolytica 6(12.2\%) ,however 34(41.0\%) were mixed infection identified as E.coli with P. multocida 17(50.0\%), Staph.aureus 7(20.6\%) and Strept.pneumoniae $3(8.8 \%)$ as well as $P$. haemolytica with Staph.aureus 7(20.6\%). Pathogenicity test for P. multocida isolates revealed that all injected mice were dead through 24-48 hours. The results of the antimicrobial sensitivity test showed that Enrofloxacin, Ceftiofur, Erythromycin and Florofenicol were the most effective antibiotics for treatment.

Key words: Respiratory affections, buffalo calves, bacteriology, antibiogram.

\section{INTRODUCTION}

Respiratory affections are major problems among calves, causing severe economic losses through reduction of weight gain, high mortality rates (EL-Sebaie et al., 1984; Abd EL-Ghani et al., 1990; Youssef et al., 1992; Barrett, 1998; Selim et al., 2006).

These affections are a complex syndrome attributed to several factors involving bacterial infection, viral infection and stress factors as cold, clamp weather, dust, ammonia, over corwaing; poor ventilation as well as poor hygienic measures may influence the occurrence and severity of respiratory disease in calves (Bickert and Herdt, 1985; Woldehiwet et al., 1990).

Pneumonia is the most frequently occurring respiratory affections in domestic animals, attributed to mixed infection with different bacterial isolates and their circulating toxins. (Allan et al., 1991 and Novert, 2002). Bacteria are introduced by way of the respiratory passages and cause primary bronchiolities which spreads to involve the surrounding pulmonary parenchyma. Haematogenous infections by bacteria results in a varying 
number of septic foci which may enlarge form lung abscess. Thomson and Gilka (1974). Bacteria play a critical role in the severe pneumonia and fatalities associated with the bovine respiratory disease complex. Although numerous bacteria have the potential to cause pneumonia, only a small number of these are responsible for the majority of cases of disease Mosier (1997) and Dabo et al. (2007).

Pasteurella spp. E.coli, Staph.aureus, Streptcoccus spp. Corynebacterium spp., Klebseilla spp. and Pseudomonas spp. are claimed to be the main bacterial causes responsible for respiratory affections in calves (Elyas, 1982; Umlauft et al., 1987; Sayed et al., 2002; El-Bealway, 2003; Selim et al., 2006; Sayed and Zaitoun 2009).

\section{Therefore this study was done for:}

- Isolation and identidication of bacterial causes of respiratory affections in buffalo- calves.

- Pathogenicity of the some isolates to laboratory animals.

- Determine the antibiogram of the isolated bacteria.

\section{MATERIALS and METHODS}

\section{Animals:}

A total number of 68 buffalo-calves (20 clinically health, 38 diseased and 10- freshly dead and slaughter calves) aged from 2-8 months old of both sexes were involved in this investigation. The calves were belonged to a private farm in Dakahlia Governorate. These animals reared in unhygienic conditions during winter months. Diseased calves showing signs of respiratory troubles including rapid breathing, moist rales, congested mucous membranes, mucopurulent nasal discharge, severe dysponea and pyrexia $\left(40-41^{\circ} \mathrm{C}\right)$. Parasitological examination was done for the diseased calves to exclude those infested with internal parasites.

\section{Samples:}

Nasal swabs were collected from all animals (68). The tracheal swabs (10), lung tissues (10) and lymph nodes(10) were only collected from the freshly dead and emergency slaughtered calves. The samples(98) were taken under aseptic conditions and sent without delay to the laboratory for bacteriological examinations.

\section{Bacteriological examination:}

Nasal and tracheal swabs were inoculated into nutrient broth and incubated at $37^{\circ} \mathrm{C}$ for $24 \mathrm{hr}$ and then subcultured into $10 \%$ Blood sheep agar, MacConkeys agar, Nutrient agar, XLD and Mannitol salt agar plates 
and incubated at $37^{\circ} \mathrm{Cfor} 24-48 \mathrm{hr}$. The surface of the lung tissues were sterilized with a hot spatula then, the tissue was incisized with sterile scalpel and with sterile platinum loop samples were taken and inoculated in the previously mentioned media. Suspected colonies were characterized on the bases of morphologically and colonial appearance according to Finegold and Martin (1982). The pure colonies were identified biochemically according to Koneman et al. (1997) and Quinn (2002).

Pathogenicity and virulence of isolated pasteurella multocida in mice:

This was done according to Wessman (1964), where four white mice of $(25-30$ grams) were used for each isolate. The mice was injected $\mathrm{I} / \mathrm{P}$ by $0.1 \mathrm{ml}$ of bacterial suspension $\left(1.5 \times 10^{8}\right.$ organism per $\mathrm{ml}$.) according to Stamp et al. (1955). One mouse was kept as a control for each isolate and injected $1 / \mathrm{p}$ with $0.1 \mathrm{ml}$ sterile normal saline. All dead mice showed post mortem changes. Re-isolation of inoculated strains from heart blood, lung and liver of dead mice was carried out. The prepared blood films were stained with Leshiman's stain for showing the characteristic bipolarity features of $P$. multiocida organisms.

\section{Antibiotic sensitivity test:}

Antibiotic sensitivity test for pathogenic bacterial isolates was done by the disc diffusion methods according to Finegold and Martin (1982). Using antibiotic discs, Enrofloxacin, Erythromycin, Ceftiofur, Florofincol, Amoxicillin, Penicillin, Gentamycin and Oxytetracycline.

\section{RESULTS}

\section{The clinical signs:}

The main clinical signs of infected calves were rise of body temperature $\left(40-41^{\circ} \mathrm{C}\right)$, depression, increased eye and nasal discharge, loss of appetite, acceleration of respiration and congestion of nasal mucous membrane.

\section{Post-mortum findings:}

The post-mortum findings of lung infection were varied from severe congestion, reddish grayish exudate within the bronchi to red hepatization.

The obtained results were tabulated in Tables 1, 2, 3, 4 and 5 
Table 1: Results of bacteriological examination of respiratory affections in buffalo- calves.

\begin{tabular}{|c|c|c|c|c|c|c|c|c|c|c|}
\hline \multirow{2}{*}{$\begin{array}{c}\text { Conditions } \\
\text { of calves }\end{array}$} & \multirow{2}{*}{$\begin{array}{c}\text { No. of } \\
\text { examined } \\
\text { samples }\end{array}$} & \multicolumn{2}{|c|}{$\begin{array}{c}\text { Positive } \\
\text { samples }\end{array}$} & \multicolumn{2}{|c|}{$\begin{array}{c}\text { Negative } \\
\text { samples }\end{array}$} & \multicolumn{2}{|c|}{$\begin{array}{c}\text { Single } \\
\text { isolates }\end{array}$} & \multicolumn{2}{|c|}{$\begin{array}{c}\text { Mixed } \\
\text { isolates** }\end{array}$} & $\begin{array}{c}\text { Total } \\
\text { No. of } \\
\text { bacterial } \\
\text { isolates }\end{array}$ \\
\cline { 2 - 12 } & No. & $\%$ & No. & $\%$ & No. & $\% *$ & No. & $\% *$ & \\
\hline $\begin{array}{c}\text { Clinically } \\
\text { healthy } \\
(20)\end{array}$ & 20 & 5 & 25.0 & 15 & 75.0 & 5 & 100.0 & 0 & 0.0 & 5 \\
\hline $\begin{array}{c}\text { Diseased } \\
(38)\end{array}$ & 38 & 38 & 100.0 & 0 & 0.0 & 31 & 81.6 & 7 & 18.4 & 45 \\
\hline $\begin{array}{c}\text { Dead and } \\
\text { slaughtered } \\
(10)\end{array}$ & 40 & 40 & 100.0 & 0 & 0.0 & 13 & 32.5 & 27 & 67.5 & 67 \\
\hline Total & 98 & 83 & 84.7 & 15 & 15.3 & 49 & 59.0 & 34 & 41.0 & 117 \\
\hline
\end{tabular}

* The percentage was calculated in relation to the number of the positive samples.

** Mixed infection with two micro-organisms where the total number of bacterial isolates $[117=5+31+(7 \times 2)+13+(27 \times 2)]$

Table 2: Frequency distribution of isolated bacteria as single infection from examined calves:

\begin{tabular}{|c|c|c|c|c|c|c|c|c|c|c|c|c|c|c|}
\hline \multirow{3}{*}{ Organisms } & \multirow{2}{*}{\multicolumn{2}{|c|}{$\begin{array}{c}\begin{array}{c}\text { Clinically } \\
\text { healthy }\end{array} \\
\begin{array}{c}\text { Nasal } \\
\text { swabs (20) }\end{array}\end{array}$}} & \multirow{2}{*}{\multicolumn{2}{|c|}{$\begin{array}{c}\text { diseased } \\
\text { Nasal } \\
\text { swabs (38) }\end{array}$}} & \multicolumn{8}{|c|}{ Dead and slaughtered calves } & \multirow{2}{*}{\multicolumn{2}{|c|}{ Total }} \\
\hline & & & & & \multicolumn{2}{|c|}{$\begin{array}{c}\text { Nasal } \\
\text { swabs (10) }\end{array}$} & \multicolumn{2}{|c|}{$\begin{array}{c}\text { Tracheal } \\
\text { swabs (10) }\end{array}$} & \multicolumn{2}{|c|}{$\begin{array}{c}\text { Lung } \\
\text { tissue (10) }\end{array}$} & \multicolumn{2}{|c|}{$\begin{array}{c}\text { Lymph } \\
\text { nodes (10) }\end{array}$} & & \\
\hline & No. & $\%$ & No. & $\%$ & No. & $\%$ & No. & $\%$ & No. & $\%$ & No. & $\%$ & No. & $\% *$ \\
\hline $\begin{array}{c}\text { Pasteurella } \\
\text { multocida }\end{array}$ & 2 & 9.5 & 15 & 71.4 & 1 & 4.8 & 0 & 0.0 & 2 & 9.5 & 1 & 4.8 & 21 & 42.9 \\
\hline $\begin{array}{l}\text { Pasteurella } \\
\text { haemolytica }\end{array}$ & 0 & 0.0 & 2 & 33.3 & 1 & 16.7 & 0 & 0.0 & 1 & 16.7 & 2 & 33.3 & 6 & 12.2 \\
\hline E. coli & 1 & 9.1 & 9 & 81.8 & 0 & 0.0 & 0 & 0.0 & 0 & 0.0 & 1 & 9.1 & 11 & 22.4 \\
\hline Staph. aureus & 1 & 12.5 & 4 & 50.0 & 0 & 0.0 & 1 & 12.5 & 0 & 0.0 & 2 & 25.0 & 8 & 16.3 \\
\hline $\begin{array}{c}\text { Streptococcus } \\
\text { pneamoniae }\end{array}$ & 1 & 33.3 & 1 & 33.3 & 0 & 0.0 & 0 & 0.0 & 0 & 0.0 & 1 & 33.3 & 3 & 6.1 \\
\hline Total & 5 & 10.2 & 31 & 63.3 & 2 & 4.1 & 1 & 2.0 & 3 & 6.1 & 7 & 14.3 & 49 & 100.0 \\
\hline
\end{tabular}

*The percentage was calculated according to total number of single bacterial isolates(49). 
Table 3: Frequency distribution of isolated bacteria as mixed infection from examined calves:

\begin{tabular}{|c|c|c|c|c|c|c|c|c|c|c|c|c|c|c|}
\hline \multirow{3}{*}{ Organisms } & \multicolumn{2}{|c|}{$\begin{array}{c}\text { Clinically } \\
\text { healthy }\end{array}$} & \multicolumn{2}{|c|}{ Diseased } & \multicolumn{8}{|c|}{ Dead and slaughtered calves } & \multirow{2}{*}{\multicolumn{2}{|c|}{ Total }} \\
\hline & \multicolumn{2}{|c|}{$\begin{array}{c}\text { Nasal } \\
\text { swabs } \\
(20)\end{array}$} & \multicolumn{2}{|c|}{$\begin{array}{c}\text { Nasal } \\
\text { swabs (38) }\end{array}$} & \multicolumn{2}{|c|}{$\begin{array}{c}\text { Nasal } \\
\text { swabs (10) }\end{array}$} & \multicolumn{2}{|c|}{$\begin{array}{c}\text { Tracheal } \\
\text { swabs (10) }\end{array}$} & \multicolumn{2}{|c|}{$\begin{array}{l}\text { Lung tissue } \\
\text { (10) }\end{array}$} & \multicolumn{2}{|c|}{$\begin{array}{c}\text { Lymph } \\
\text { nodes (10) }\end{array}$} & & \\
\hline & No. & $\%$ & No. & $\%$ & No & $\%$ & No. & $\%$ & $\mathrm{No}$ & $\%$ & No. & $\%$ & No. & $\% *$ \\
\hline $\begin{array}{c}\text { Pasteurella } \\
\text { multocida }+ \\
\text { E.coli }\end{array}$ & 0 & 0.0 & 3 & 17.6 & 4 & 23.5 & 3 & 16.7 & 6 & 35.3 & 1 & 5.9 & 17 & 50.0 \\
\hline $\begin{array}{c}\text { E. coli }+ \\
\text { Staph. aureus }\end{array}$ & 0 & 0.0 & 2 & 28.6 & 2 & 28.6 & 2 & 28.6 & 0 & 0.0 & 1 & 14.3 & 7 & 20.6 \\
\hline $\begin{array}{c}\text { E. coli }+ \\
\text { Streptococcus } \\
\text { pneumoniae }\end{array}$ & 0 & 0.0 & 1 & 33.3 & 1 & 33.3 & 1 & 33.3 & 0 & 0.0 & 0 & 0.0 & 3 & 8.8 \\
\hline $\begin{array}{c}\text { Pasteurella } \\
\text { haemilytica }+ \\
\text { Staph. aureus }\end{array}$ & 0 & 0.0 & 1 & 14.3 & 1 & 14.3 & 3 & 42.9 & 1 & 14.3 & 1 & 14.3 & 7 & 20.6 \\
\hline Total & 0 & 0.0 & 7 & 20.6 & 8 & 23.5 & 9 & 26.5 & 7 & 20.6 & 3 & 8.8 & 34 & 100.0 \\
\hline
\end{tabular}

* The percentage was calculated according to total number of mixed bacterial isolates(34).

Table 4: Pathogenicity of isolated pasteurella multocida in mice.

\begin{tabular}{|c|c|c|c|c|c|c|}
\hline \multirow{2}{*}{$\begin{array}{c}\text { No. of } \\
\text { isolates }\end{array}$} & $\begin{array}{c}\text { No. of } \\
\text { inoculated mice }\end{array}$ & \multicolumn{3}{|c|}{ Time of death post intraperitoneal } & \multirow{2}{*}{$\begin{array}{c}\text { Mortality } \\
\text { rate }\end{array}$} \\
\cline { 3 - 6 } & $\begin{array}{c}\text { Less than } \\
24 \mathrm{hr} .\end{array}$ & $24 \mathrm{hr}$. & $48 \mathrm{hr}$. & $72 \mathrm{hr}$. & \\
\hline 21 & 63 & 20 & 28 & 15 & 0 & $100 \%$ \\
\hline
\end{tabular}


Table 5: Results of antibiotics sensitivity test to some pathogenic bacterial isolates

\begin{tabular}{|c|c|c|c|c|c|c|c|c|c|c|}
\hline \multirow[b]{2}{*}{$\begin{array}{l}\text { Antibiotic } \\
\text { disc }\end{array}$} & \multicolumn{2}{|c|}{$\begin{array}{l}\text { Pasteurlla } \\
\text { multocida } \\
(14)^{*}\end{array}$} & \multicolumn{2}{|c|}{$\begin{array}{c}\text { Pasteurella } \\
\text { haemolytica } \\
(4)^{*}\end{array}$} & \multicolumn{2}{|c|}{$\begin{array}{c}\text { E. coli } \\
(9)^{*}\end{array}$} & \multicolumn{2}{|c|}{$\begin{array}{c}\text { Staph. } \\
\text { aureus } \\
(6)^{*}\end{array}$} & \multicolumn{2}{|c|}{$\begin{array}{c}\text { Streptococcus } \\
\text { pneumoniae } \\
(3)^{*}\end{array}$} \\
\hline & No. & $\%$ & No. & $\%$ & No. & $\%$ & No. & $\%$ & No. & $\%$ \\
\hline $\begin{array}{c}\text { Enrofloxacin } \\
10 \mu \mathrm{g} \\
\end{array}$ & 12 & 85.5 & 3 & 75.0 & 8 & 88.9 & 5 & 83.3 & 2 & 66.7 \\
\hline $\begin{array}{c}\text { Erythromycin } \\
10 \mu \mathrm{g} \\
\end{array}$ & 9 & 64.3 & 2 & 50.0 & 7 & 77.8 & 4 & 66.7 & 2 & 66.7 \\
\hline $\begin{array}{c}\text { Ceftiofur } \\
30 \mu \mathrm{g} \\
\end{array}$ & 10 & 71.4 & 3 & 75.0 & 8 & 88.9 & 5 & 83.3 & 2 & 66.7 \\
\hline $\begin{array}{c}\text { Gentamycin } \\
10 \mu \mathrm{g}\end{array}$ & 10 & 71.3 & 2 & 50.0 & 6 & 66.7 & 3 & 50.0 & 1 & 33.3 \\
\hline $\begin{array}{c}\text { Florofincol } \\
10 \mu \mathrm{g}\end{array}$ & 8 & 57.1 & 2 & 50.0 & 7 & 77.8 & 4 & 66.7 & 2 & 66.7 \\
\hline $\begin{array}{c}\text { Amoxycillin } \\
30 \mu \mathrm{g} \\
\end{array}$ & 8 & 57.1 & 2 & 50.0 & 6 & 66.7 & 2 & 33.3 & 3 & 33.3 \\
\hline $\begin{array}{c}\text { Penicillin } \\
10 \mu \mathrm{g}\end{array}$ & 3 & 21.4 & 0 & 0.0 & 1 & 11.1 & 1 & 16.7 & 2 & 66.7 \\
\hline $\begin{array}{c}\text { Oxytetracycline } \\
30 \mu \mathrm{g} \\
\end{array}$ & 6 & 42.9 & 1 & 25.0 & 4 & 44.4 & 3 & 50.0 & 1 & 33.3 \\
\hline
\end{tabular}

*Number of the bacterial isolates which used in sensitivity test.

\section{DISCUSSION}

Commensal bacteria present in the respiratory system may cause disease when animals are subjected to stress factors Palotay and Newhall (1985). Respiratory affections attributed to the mixed infection with different bacterial isolates and their circulating toxins was reported by Jones et al. (1997). The diseased buffalo-calves in this study were suffering from severe dyspnoea, weakness and increase in the heart and respiratory rates. Also congested mucous membranes, nasal discharge and moist cough. Similar finding were previously described by Youssef et al. (1992) and El-Sheikh et al. (1994).

Bacteriological examination of the samples Table (1) revealed that the higher incidence of bacteria was obtained from diseased calves 38 $(100 \%)$ and $(100 \%)$ from 40 samples of dead and slaughtered calves (10 nasal swabs, 10 tracheal swabs, 10 lung tissue and 10 lymph node samples). Such high incidence of isolation was also reported by several investigators Barbour et al. (1997); EL-Enbawy (1986); Selim et al. 
(2006). 49 of 83 positive samples (59.0\%) were found exhibiting single types of bacteria (single infection) while the remaining 34 isolates $(41.0 \%)$ were found having mixed infection as shown in table (1), it is commonly to detect pulmonary mixed infection since the bovine respiratory air pathways act as reservoirs for potential pathogenic microorganisms, which develop pneumonia on the onset under stress factors, decline of hygienic measurements or climatic conditions (Yehia, 2000 and Moustafa, 2004).

In our results, isolation of the single bacteria and mixed bacteria from diseased, dead and slaughtered calves were detected also by Sayed et al. (2002); Selim et al. (2006); Sayed and Zaitoun (2009). who isolated the bacteria in single and mixed infection from calves suffering from respiratory troubles. Identification of the respiratory affections pathogens as a single infection in the present work, cleared the isolation of pasteurella multocida (42.9\%), E.coli (22.4\%)and Staph. aureus (16.3\%) as shown in Table (2) which were the most common pneumonic bacteria isolated from respiratory tract of the buffalo-calves. Widely documented (Saleh and EL-Bably, 1998; Zaki et al., 2002; Mona, 2005). Also Sayed and Zaitoun (2009) recorded that the Staph.aureus (22.4\%), E.coli (18.2\%) and P.multocida $(15.9 \%)$ were the most common isolated bacterial from pneumonic buffalo-calves. Streptococcus pneumoniae was(6.1\%) in our results. Higher incidences were recorded by Selim et al. (2006) who isolated Strept.pneumonia (14.8\%) from cows suffering from respiratory manifestation. Also Smiko and Lehocky (1993) found that the main causative bacterial agents of calves died from respiratory infection were Strept. Pneumonia in an incidence (18.7\%). Pasteurella haemolytica was isolated at percentage of (12.2\%) Table (2), nearly similar results were obtained by Zaki et al. (2002) who isolated P.heamolytica (8.8\%) from pneumonic buffalo-calves, low incidence was recovered by kaoud et al. (2010) who isolated P.haemolytica (3.9\%)from respiratory tract of buffaloes. The variation in isolation percentage may be attributed to change in hygienic measure, stress factors, change in management and immune status of infected animals Sedeek and Thabet (2001).

Pasteurella multocida and E.coli, represent the most common Gram negative bacteria isolated from pneumonic buffalo-calves. These results were inagreement with El-Hamamy et al. (1999); Sayed et al. (2002); El-Bealawy (2003). Table (2) showed that the Staph. aureus was isolated from (16.3\%) of these cases and represents the most common Gram positive bacteria. These findings were coincided with that obtained by Sayed et al. (2002) and Sayed and Zaitoun (2009).

Pasteurella multocida is one of the main bacterial causes of bovin pneumonia it has been frequently isolated from pneumonic and healthy 
calves. By itself, this bacterium dose not usually cause serious disease, but it can be a significant pathogen of associated with other bacteria, viruses or Mycoplasma as predisposing factor when calves are stressed (Shayegh et al. 2010 and Khin et al. 2010). Percentage of P. multocida isolates in the present work from affected buffalo-calves $(42.9 \%)$ while higher incidence of $P$. multocida were $70 \%$ obtained by Erdag et al. (1993). The low incidence was recovered by Novert (2002) who isolated $P$. multocida (8\%) from peumonic lung of newly born calves. E.coli was one the most important causes of early onset infection and frequent causative agent of respiratory troubles in calves (Mona, 2005). In present study, the percentage of E.coli (22.4\%), similar results were reported by Sayed et al. (2002) who isolated E.coli (23.8\%) from pneumonic calves, while low incidence was (5.6\%) Selim et al. (2006). The isolated bacteria as mixed infection Table (3) included pasteurella multocida with E.coli in 17cases (50.0\%), E.coli with Staph. aureus in 7cases (20.6\%), E.coli with Strept. Pneumoniae in 3cases $(8.8 \%)$ and P.haemolytica with Staph. aureus in7 cases (20.6\%).While Sayed et al. (2002) isolated p.multocida with E.coli (38.9\%), E.coli with Staph.aureus (22.2\%), Streptococcus pneumoniae with E.coli (11.1\%), Strept.pyogenes with Staph. aureus (11.1\%) and Kl.pneumoniae with Corynebacterium ovis (5.6\%) from healthy and diseased calves. Those demonstrate the complexity of the disease where Staph. aureus may predispose the animal infection by coliform organisms or other pathogens. (Elbatrawy et al., 1992; Roberson et al., 1994; Sedeek and Thabet, 2001). Despite of p. multocida being nasopharyngeal commensally Dabo et al. (2007), whene invade lung tissue under stress factors, its virulence exaggerates and pathogenicity differs Christensen et al. (2004), depending upon their outer membrane proteins Dabo et al. (2007). The results of the pathogenicity test for $p$. multocida in mice table (4) revealed that all isolates were highly pathogenic to mice produce acute septicemia and death within 24- 48 hours post inoculation. Re-isolation of p.multocida was recovered from heart blood, lungs, liver and spleen of died mice. None of the control mice died during the experimental period. This agreed with the results obtained by (El-Sheikh et al., 1994; Zaki et al., 2002; Moustafa, 2004; Sayed and Zaitoun 2009).

Regarding to the sensitivity test carried out on several types of antibiotics as in Table (5) these results indicates that most bacterial isolates were highly sensitive to Enrofloxacin, Erythromycin, Ceftiofur and Florfinicol, these findings were partially coincided with that obtained by Selim et al. (2006). On the other hand Sedeek and Thabet (2001) recorded that the bacterial isolates from pneumonic cattle were more sensitive to Spectrama. 
From this study it can concluded that the correct diagnosis ,isolation and identification of pathogenic and potentially pathogenic isolates as P. multocida, E.coli and Staph.aureus have an important role in the respiratory affections in buffalo-calves, so adequate hygienic measures and proper management may reduce the degree of animals exposure to disease producing agents, beside using the effective antibiotics for treatment the diseased cases.

\section{REFFERANCES}

Abd El-Ghani, M.; El-Seedy, F.R.; Shoukry, S. and Rida, E.M. (1990): Incidence and bacterial causes of mortality with respiratory disorders. Vet. Med. J. Giza, 38 (2) 233-243.

Allan, J.W.; Batman, K.G.; Viel, L.; Rosendal, S. and Shewen, P.E. (1991):

The microbial flora of the upper and loer respiratory tracts of feedlot calves with undifferentiated bovine respiratory diseases. Bovine practitioner, 26: 162-168.

Barbour, E.K.; Nabbut, N.H.; Hamadeh, K.S. and Al-Nakkkhli, H.M. (1997): Bacterial identify and charcteristics in healthy and unhealthy respiratory tracts of sheep and calves. Vet. Res. Commun. 21 (6) 421-430.

Barrett, D.C. (1998): Bovine respiratory diseases. A clinician's perspective. Cattle practice 6: 251-255.

Bickert, W.G. and Herdt, T.H. (1985): Environmental aspects of dairy calves housing. Compendium on continuing Education for the practicing Veterinarians 7: 5309.

Christensen, H.; Angen, Q.; Olsen, J.E. and Bisgaard, M. (2004): Revised description and classification of atypical isolates of pasteruella multocida from bovine lungs based on genotyping characterization to include variants previously classified as biovar 2 of pasteruella canis and pasteruella avium. Microbiology, 150 6: 1757-1767.

Dabo, S.M.; Taylor, J.D. and Confer, A.W. (2007): Pasteurella multocida and bovine respiratory disease. Anim. Health Res.Rev.,8(2): 129-150.

El-Sheikh, A.R.; Mohga Abd El-Razek; Esmat, M. and Asma, A.A. (1994): Clinical, biochemical, and bacteriological studies on respiratory affections in buffalo-calves $2^{\text {nd }}$ Vet. Med. Cong. Zagazig University, pp: 646-657.

Elbattarwy, N.E.; El-Grahy, M.M.; El-Rashidy, A.A.; Girgis, S.M. and Tawfik, M.S. (1992): Incidence of microorganisms isolated from 
respiratory tract of apparently healthy and diseased buffalo-calves. Beni-Suef, Vet. Med. Res., Vol. 2, No.1336-376.

El-Bealawy, M.A. (2003): Hematological and biochemical studies on pneumonia in new born calves Egypt, J. Agric. Res.,81 (1) pp: 253-261.

El-Enbawy, M. (1986): Investigation on some microbiological causes of respiratory affection in buffalo- calves. M.v.sc. Thesis (Microbiology) Fac. of Vet. Med. Cairo University.

El-Hamamy, M.M.; El-Boushy, M.E. and Fetaih, H.A. (1999): Some studies on newly born calves problems with relationship to their immune status. Suez Canal Vet. Med. J., 11 (2): 289-308.

El-Sebaie, A.H.; Ibrahim, A.H.; Ibrahim, A.A.; Hofmann, W. and Amer, A.A. (1984): Investigation on an outbreak of enzootic bronchopneumonia in fattening buffalo-calves in Assiut A.R.E. 1Clinical, micobiological and heamatological studies, Assiut Vet. Med. J. Vol.11, No. 22: 163-167.

Elyas, A.H. (1982): Mycological and bacteriological studies on the causes of pneumonia affecting buffalo-calves. Ph. D. Thesis (Microbiology), Fac. Vet. Med., Assiut University.

Erdag, O.; Erdogan, I.; Trkaslan, J. and Grel, A. (1993): Isolation, identification and antibiotic sensitivity testing of mycoplasma and bacterial agents from pneumonic calf lungs. Pendik Vet. Mikrobi. Dergisi, 24 (2): 143-148.

Finegold, S.M. and Martin, W.J. (1982): Bailey and Scott,s Diagnostic Microbiology. $6^{\text {th }}$ Ed.The C.V Moshy Co., St. Lowis, Toronato, London.

Jones, T.C.; Hunt, R.D. and King, N.W. (1997): Veterinary pathology, $6^{\text {th }}$ ed. Williams and Wilkins Company U.S. A.

Kaoud, H.A.; El-Dahshan, A.R.; Zaki, M.M. and Nasr, S.A. (2010): EcoEpidemiologic aspects of Mannheimia haemolytica in Egypt. Reseacher 3(2)pp: 43-50. (ISSN : 1553-9865) .

Khin, M.N.; Zamri-Saad, M. and Noordin, M.M. (2010): Pathological changes in the lungs of calves following interatracheal exposure to pasteurella B:2. Pertanika J. Trop. Agric. Sci 33 (1) P: 113-117.

Koneman, E.W.; Allen, S.D.; Danda, W.M.; Sohrechenberger, P.C. and Winn, W.C. (1997): Colour Atlas and Textbook of Diagnostic Microbiology . 4th Ed. J.B. Lippincott Co., U.S.A

Mona, A.EL-Shabrawy (2005): Approaching study on the potential role of pulmonary surfactant in innate lung defense buffalo-calves J.Egypt.Vet.Med Assoc. 65(2): 185-202. 
Mosier, D.A. (1997): Meat and Livestock Commission Queensway House, Bletchly, UK. Vet. Clin. North, Am. Food Anim. Pract., 13(30): 483-493

Moustafa, A.H. (2004): Studies of aerobic bacterial causes of respiratory affection in slaughtered camels in Dakahlia Governorate.Assiut Vet. Med. J. 50 (102): 95-105.

Novert, M. Hafez (2002): Bacteriological and mycological studies on lung infection in newly born calves. J. Egypt Vet. Med. Assoc., 62 (4): 189- 194.

Palotay, J. and Newhall, J. (1985): Pneumonia in newly weaned calves. Am. Vet. Med. Assoc. 133: 353-359.

Quinn, P.J.; Markey, B.K.; Carter, M.E.; Donnelly, W.J. and Leonard, F.C. (2002): Veterinary Microbiology and Microbial Disease. Blackwell, U.K.

Roberson, J.R.; Fox, L.K.; Hancok, D.D.; Gay, J.M. and Besser, T.B. (1994): Etiology of Staphylococcuc aureus isolated from various sites on dairy farms J.of Dairy Science 77 (11): 3354-3364.

Saleh, L.A. and El-Bably, M.A. (1998): Hygienic studies for control of pneumonia in buffalo-calves with special reference to its clinicolaboratory diagnosis $8^{\text {th }}$ sci Cong. Fac. Vet. Med. Assiut University, Egypt, pp173-187.

Sayed, S.M. and Zaitoun (2009): Aerobic bacterial pathogens of pneumonic feedlot buffalo-calves, in Assiut Governorate, Egypt. Ass. Univ. Environ. Res. Vol. 12 No 1. p. 55-61.

Sayed, A.S.; Ali, A.A.; Mottelib and Abd El-Rahman, A.A. (2002): Bronchopneumonia in buffalo-calves in Assiut Governorate. 1Studies on bacterial causes, clinical, haematological and biochemical changes associated with the disease. Assiut, Vet. Med. J.Vol.46 No. 92, pp: 138-155.

Sedeek, S.R. and Thabet, A.E. (2001): Some studies on bacterial causes of pneumonia in cattle in Assiut Governorate. Assiut Vet. Med. J., 45(90)pp: 243-255.

Selim, M.A.; Hamouda, A.M. and Alganzoury, H. (2006): Bacterial causes of respiratory manifestation in dairy cows and effect on properties in milk in Sharkia Province.Zag. Vet. J. (ISSN. 1110-1458) Vol. 34, No.3 pp: 97-103.

Shayegh, J.; Atashpaz, S.; El Salehi, T.Z. and Hejazi, M.S. (2010): Potential of pasteurella multocida isolated from healthy and diseased cattle and buffaloes in induction of diseases. Bull.Vet. Inst. Pulawy.54, pp: 299-304. 
Smiko, S. and Lehocky, J. (1993): Bacteriological findings in the lung of calves with respiratory syndrome. Veternariae Service 43(11): 412-413.

Stamp, J.; Watt, J. and Thomlinson, J. (1955): Pasteurella heamolytica septicemia of calves.J. Comp. Path., 65: 183-186.

Thomson, R.G. and Gilka, F. (1974): A brief review of pulmonary clearance of bacterial aerosols emphasizing aspects of particular revalence to Vet. Med. Can. Vet. J. (15) 99.

Umlauft, K.D.; Schulz, G.; Franl, F.; Schanfelder, U.; Pannwitz, S.; Blohm, H.; Clans, D. and Liebig, F. (1987): Diagnosis of infections in calf pneumonia Monatshefte fur Veterinary Medizin, 42 (16) 583-588.

Woldehiwet, Z.; Mamache, B. and Rowan, T.G. (1990): The effect of age, environmental temperature and relative humidity on the bacterial flora of the upper respiratory tract in calves. Br. Vet. J. 146: 211-218.

Wessman, G.E. (1964): Interrelation of smooth and non-smooth variant in dissociation of pasteurella haemolytica. J. Bact., 88 pp: 325-360.

Yehia, B.M. (2000): Investigation of respiratory problems in calves.M. V.Sc. Thesis (Infectious diseases) Fac. Vet. Med. Zag. Univ. Benha Branch.

Youssef, M.A.; Waffa, M.; Abdel-Razek; El-Sadawy, H.A. and Seleim, A.M. (1992): Clinical and laboratory studies on an outbreak of bacterial respiratory troubles in buffalo-calves in Egypt $.5^{\text {th }}$ Sci. Cong. Fac. Vet. Med. Assiut University, Egypt. 92-103.

Zaki, E.R.; Tanios, A.; Novert, M.; Hafez and Yanni, A. (2002): Studies on pasteurella species in buffalo-calves. J. Egypt. Vet. Med. Assoc. 62(6a): 111-118. 